\title{
Chryseobacterium aquaticum sp. nov., isolated from a water reservoir
}

Correspondence

Jung-Sook Lee

jslee@kribb.re.kr

\author{
Kwang Kyu Kim, Keun Chul Lee, Hee-Mock Oh and Jung-Sook Lee
}

Korean Collection for Type Cultures, Biological Resource Center, Korea Research Institute of Bioscience and Biotechnology, 52 Eoeun-dong, Yuseong-gu, Daejeon 305-806, Republic of Korea
The genus Chryseobacterium (type species, Chryseobacterium gleum), within the family Flavobacteriaceae, was erected by Vandamme et al. (1994) to accommodate six species formerly classified within the genus Flavobacterium. A number of novel Chryseobacterium species have been described since then, while two former Chryseobacterium species, namely Chryseobacterium meningosepticum and Chryseobacterium miricola, have been transferred to the newly erected genus Elizabethkingia (Kim et al., 2005). At the time of writing, the genus Chryseobacterium comprised 22 recognized species isolated from a variety of environmental sources (including soil, water, sludge and plants), food products (such as fish, meat, milk, poultry and lactic acid beverages) and human clinical specimens (Bernardet et al., 2006).

During investigation of the bacterial community present in a water reservoir in Buyeo, Korea, strains 10-46 ${ }^{\mathrm{T}}$ and 10-106 were recovered, showing yellow-pigmented colonies when grown on nutrient agar (Difco) at $30{ }^{\circ} \mathrm{C}$. On the basis of preliminary $16 \mathrm{~S}$ rRNA gene sequence comparisons, the strains were found to belong to the genus Chryseobacterium, but they showed low levels of $16 \mathrm{~S}$ rRNA gene sequence similarity $(<97 \%)$ to all recognized species of this genus. To elucidate the taxonomic status of the two isolates further, they were subjected to a polyphasic investigation.

For most experiments, strains were cultivated on nutrient agar or broth (Difco) at $30{ }^{\circ} \mathrm{C}$ for $48 \mathrm{~h}$. For analysis of fatty

The GenBank/EMBL/DDBJ accession numbers for the 16S rRNA gene sequences of strains $10-46^{\top}$ and $10-106$ are AM748690 and AM748691, respectively. acids, strains were cultivated on trypticase soy agar (Difco) at $30{ }^{\circ} \mathrm{C}$ for $48 \mathrm{~h}$. Chryseobacterium indoltheticum KCTC $2920^{\mathrm{T}}$, Chryseobacterium scophthalmum KCTC $2907^{\mathrm{T}}$, Chryseobacterium soldanellicola KCTC $12382^{\mathrm{T}}$ and Chryseobacterium balustinum KCTC $2903^{\mathrm{T}}$, grown under identical conditions, were used as reference strains for fatty acid analysis.

The Gram reaction was performed as described by Gerhardt et al. (1994). Cell morphology and motility were observed under a light microscope (Nikon Optiphot-2, $\times 1000$ magnification) with cells grown for 1-3 days. Motility was tested by the hanging-drop technique (Skerman, 1967). Flexirubin-type pigments were detected with $20 \% \mathrm{KOH}$ according to the method of Fautz \& Reichenbach (1980). Oxidase activity was tested by using Bactident-Oxidase strips (Merck) and catalase activity was tested by using $3 \% \mathrm{H}_{2} \mathrm{O}_{2}$. Growth was investigated at 5, 10, $15,20,25,30,37$ and $42{ }^{\circ} \mathrm{C}$, in the presence of $1,2,3$ and $5 \% \mathrm{NaCl}$ and at $\mathrm{pH} 5-10$ (in increments of $1 \mathrm{pH}$ unit). The following biological buffers were used to adjust the pH: $\mathrm{Na}_{2} \mathrm{HPO}_{4} / \mathrm{NaH}_{2} \mathrm{PO}_{4}$ for $\mathrm{pH} 5-7$ and $\mathrm{Na}_{2} \mathrm{CO}_{3} /$ $\mathrm{NaHCO}_{3}$ for pH 8-10 (Gomori, 1955; Bates \& Bower, 1956). Growth on MacConkey agar (Difco) was investigated. Hydrolysis of casein and starch was tested on casein agar and starch agar (Difco). Carbon source utilization tests were performed by using GN2 microplates (Biolog) according to the manufacturer's instructions. Acid production tests and additional physiological tests were performed by using API 20E, API 20NE, API $50 \mathrm{CH}$ and API ZYM galleries according to the instructions of the manufacturer (bioMérieux). 


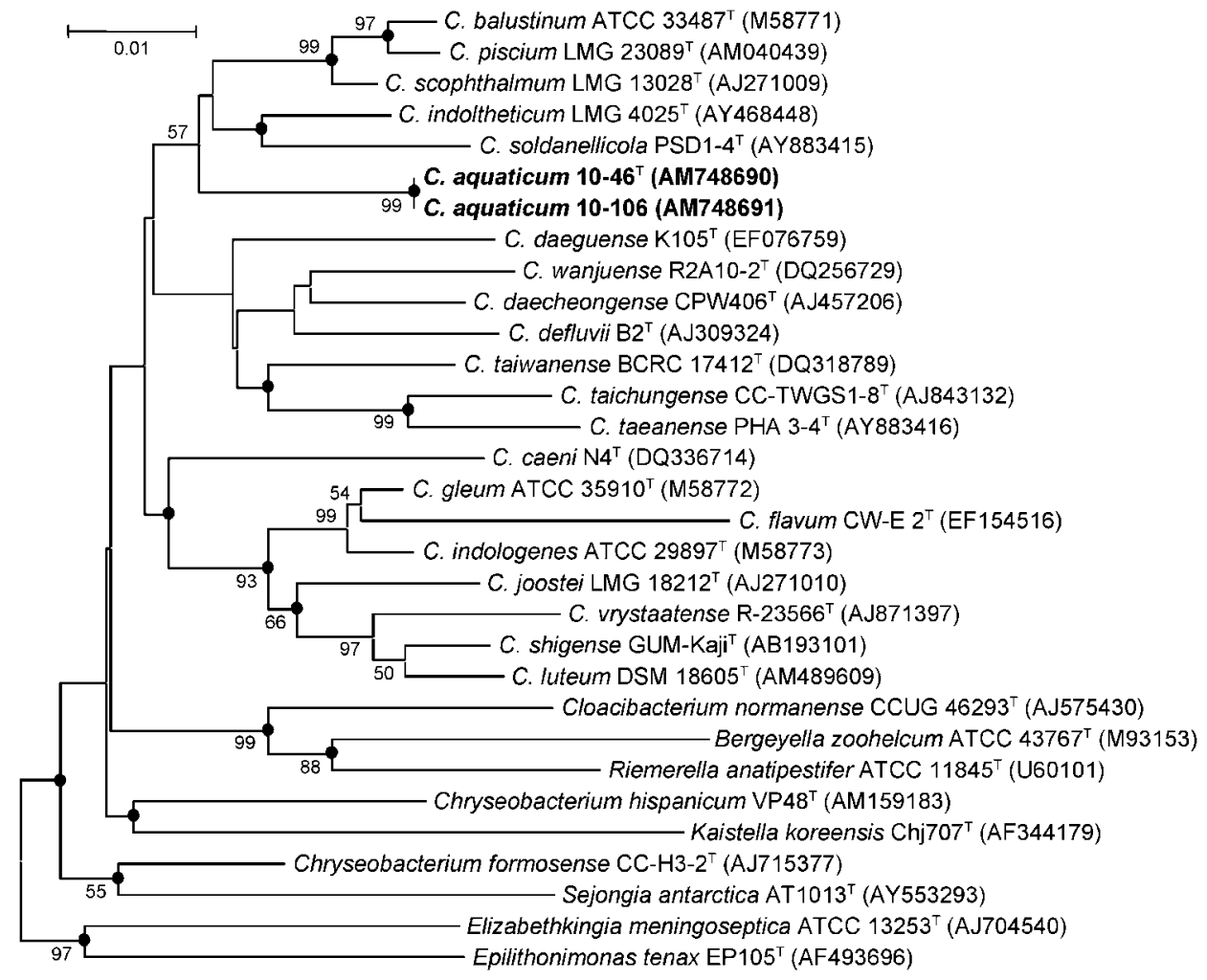

Fig. 1. Phylogenetic tree based on $16 \mathrm{~S}$ rRNA gene sequences, constructed according to the neighbour-joining method, showing the positions of strains $10-46^{\top}$ and 10-106, other Chryseobacterium species and related members of the family Flavobacteriaceae. Dots indicate branches that were also found with the maximum-parsimony treeing algorithm. Numbers at branch points refer to bootstrap percentages (from 1000 resamplings; only values $\geqslant 50 \%$ are shown). Bar, 1 substitution per 100 nucleotide positions.

Fatty acid methyl esters were prepared and analysed as described by Klatte et al. (1994) by using the standard Microbial Identification System (MIDI Inc.) for automated GC analysis (Sasser, 1990; Kämpfer \& Kroppenstedt, 1996). Isoprenoid quinones were extracted with chloroform/ methanol $(2: 1, \mathrm{v} / \mathrm{v})$ and purified by using TLC on Kieselgel $60 \mathrm{~F}_{254}$ plates (Merck; $20 \times 20 \mathrm{~cm}, 0.5 \mathrm{~mm}$ thickness) with petroleum ether/diethyl ether $(9: 1, \mathrm{v} / \mathrm{v})$ as the solvent. Quinones were identified by using reversedphase HPLC, as described by Shin et al. (1996). Polar lipids were extracted, examined by two-dimensional TLC and identified according to Komagata \& Suzuki (1987).

Extraction of genomic DNA, PCR-mediated amplification of 16S rRNA genes and sequencing of purified PCR products were carried out according to Rainey et al. (1996). The 16S rRNA gene sequences were aligned with published sequences retrieved from EMBL by using CLUSTAL_X (Thompson et al., 1997) and edited via the BioEdit program (Hall, 1999). Phylogenetic trees were constructed on the basis of the neighbour-joining (Saitou \& Nei, 1987) and maximum-parsimony (Fitch, 1971) methods; distances were estimated by the method of Jukes \& Cantor (1969) by using MEGA version 2.1 (Kumar et al., 2001). The resultant tree topologies were evaluated by bootstrap analysis (Felsenstein, 1985) based on 1000 resampled datasets. DNA G + C contents were determined by HPLC, following hydrolysis, as described by Tamaoka \& Komagata (1984), and non-methylated $\lambda$ DNA (Sigma) was used as a standard. DNA-DNA hybridization was performed fluorometrically (Ezaki et al., 1989) by using DNA probes labelled with photobiotin (A1935; Sigma) and 96-well microdilution plates (Greiner Bio-One) at $37{ }^{\circ} \mathrm{C}$.

Analysis of the almost-complete 16S rRNA gene sequences (approximately $1420 \mathrm{nt}$ ) of strains $10-46^{\mathrm{T}}$ and $10-106$ indicated that they belonged to the genus Chryseobacterium; sequence similarity ranges from 91.8 to $99.1 \%$ among the type strains of recognized species of the genus Chryseobacterium. Strains $10-46^{\mathrm{T}}$ and $10-106$ shared $99.9 \% 16 \mathrm{~S}$ rRNA gene sequence similarity. The novel strains showed highest levels of 16S rRNA gene sequence similarity to C. indoltheticum ATCC $27950^{\mathrm{T}}$, C. scophthalmum LMG $13028^{\mathrm{T}}$ and C. soldanellicola KCTC $12382^{\mathrm{T}}$, with values of $96.9,96.8$ and $96.7 \%$, respectively, which are below the level indicative of relatedness at the species level (Stackebrandt \& Goebel, 1994). The levels of 16S rRNA gene sequence similarity with other recognized 
Table 1. Characteristics that differentiate strains $10-46^{\top}$ and $10-106$ from their closest phylogenetic neighbours in the genus Chryseobacterium

Strains: $1,10-46^{\mathrm{T}} ; 2$, 10-106; 3, C. indoltheticum KCTC $2920^{\mathrm{T}}$; 4, C. scophthalmum $\mathrm{KCTC} 2907^{\mathrm{T}}$; 5, C. soldanellicola KCTC $12382^{\mathrm{T}}$; 6 , C. balustinum KCTC $2903^{\mathrm{T}}$; 7, C. piscium LMG 23089 ${ }^{\mathrm{T}}$. Data are from Kim et al. (2005), Park et al. (2006), de Beer et al. (2006) and the present study. +, Positive; - , negative; NA, no data available.

\begin{tabular}{|c|c|c|c|c|c|c|c|}
\hline Characteristic & 1 & 2 & 3 & 4 & 5 & 6 & 7 \\
\hline DNA G $+C$ content $(\mathrm{mol} \%)$ & 38.5 & 38.3 & 33.8 & 34.1 & 28.8 & 34.7 & 33.6 \\
\hline Indole production & - & - & + & - & - & + & + \\
\hline Nitrate reduction & - & - & - & - & - & + & + \\
\hline \multicolumn{8}{|l|}{ Growth at/on: } \\
\hline $37^{\circ} \mathrm{C}$ & + & + & + & - & + & - & - \\
\hline \multicolumn{8}{|l|}{ Acid production from: } \\
\hline Fructose & + & + & - & - & - & + & NA \\
\hline Maltose & + & + & + & - & - & - & NA \\
\hline Sucrose & + & + & - & - & - & - & NA \\
\hline Trehalose & + & + & - & + & - & - & $\mathrm{NA}$ \\
\hline \multicolumn{8}{|l|}{ Utilization of: } \\
\hline$\alpha$-Ketobutyric acid & + & - & - & + & + & - & $\mathrm{NA}$ \\
\hline Malonic acid & + & - & - & - & - & - & NA \\
\hline Propionic acid & + & + & - & + & + & - & NA \\
\hline Succinic acid & + & + & + & + & - & + & + \\
\hline Glycyl L-aspartic acid & + & + & + & + & - & + & NA \\
\hline L-Leucine & + & + & + & + & - & - & NA \\
\hline DL-Carnitine & + & - & - & - & - & - & NA \\
\hline Inosine & - & - & + & + & - & + & NA \\
\hline Uridine & + & + & + & + & - & + & NA \\
\hline Thymidine & - & - & - & + & - & + & NA \\
\hline Glucose 1-phosphate & + & + & + & + & - & + & NA \\
\hline 2-Naphthyl $\alpha$-D-glucopyranoside ${ }^{\star}$ & - & - & + & + & + & + & NA \\
\hline 6-Bromo-2-naphthyl $\beta$-D-glucopyranoside ${ }^{*}$ & - & - & - & - & - & + & NA \\
\hline 1-Naphthyl $N$-acetyl- $\beta$-D-glucosaminide ${ }^{*}$ & - & - & + & + & - & + & NA \\
\hline
\end{tabular}

${ }^{*}$ Data from API ZYM tests. The intensity of the colour was measured on a scale from 0 to 5 and was interpreted as negative when a value was 0 or 1 and positive when values ranged from 2 to 5 (Mudarris et al., 1994).

Chryseobacterium species were $92.8-96.6 \%$. In the phylogenetic tree, strains $10-46^{\mathrm{T}}$ and $10-106$ occupied a distinct position and formed a relatively stable branch with $C$. indoltheticum, C. scophthalmum, C. soldanellicola, C. balustinum and Chryseobacterium piscium (Fig. 1).

DNA-DNA hybridization experiments were performed to confirm the taxonomic status of the novel strains. Strains $10-46^{\mathrm{T}}$ and 10-106 shared $90 \%$ DNA-DNA relatedness, and showed levels of relatedness of 15-39\% with $C$. indoltheticum KCTC $2920^{\mathrm{T}}$, C. scophthalmum KCTC $2907^{\mathrm{T}}$ and C. soldanellicola KCTC $12382^{\mathrm{T}}$. Consequently, the DNA-DNA hybridization results confirmed that strains $10-46^{\mathrm{T}}$ and $10-106$ belong to a distinct genomic species (Wayne et al., 1987).

The morphological, biochemical and chemotaxonomic characteristics of strains $10-46^{\mathrm{T}}$ and $10-106$ are given in 
Table 2. Cellular fatty acid profiles of strains $10-46^{\top}$ and $10-$ 106 and their closest phylogenetic neighbours in the genus Chryseobacterium

Strains: $1,10-46^{\mathrm{T}} ; 2,10-106 ; 3$, C. indoltheticum KCTC $2920^{\mathrm{T}} ; 4$, C. scophthalmum KCTC $2907^{\mathrm{T}}$; 5, C. soldanellicola KCTC $12382^{\mathrm{T}} ; 6$, C. balustinum KCTC $2903^{\mathrm{T}}$; 7, C. piscium LMG $23089^{\mathrm{T}}$. Data for $C$. piscium were taken from de Beer et al. (2006). All other data are from the present study. Growth conditions for C. piscium differed from those used herein. Fatty acids are listed using standard abbreviations (number of carbon atoms : number of double bonds). Fatty acids that amounted to less than $1.0 \%$ of the total fatty acids in all strains studied are not shown. Therefore, percentages do not add to $100 \%$. tr, Trace $(<1.0 \%)$; ND, not detected; ECL, equivalent chain-length (i.e. the identity of the fatty acid is unknown).

\begin{tabular}{|lccccccc|}
\hline Fatty acid & $\mathbf{1}$ & $\mathbf{2}$ & $\mathbf{3}$ & $\mathbf{4}$ & $\mathbf{5}$ & $\mathbf{6}$ & $\mathbf{7}$ \\
\hline $13: 0$ iso & 2.6 & 2.6 & 1.2 & $\operatorname{tr}$ & 1.4 & 1.1 & $\operatorname{tr}$ \\
Unknown 13.566 & 1.3 & 1.5 & 1.3 & 3.0 & 2.1 & 2.6 & $\operatorname{tr}$ \\
$14: 0$ & 1.2 & 1.3 & $\operatorname{tr}$ & $\mathrm{ND}$ & $\operatorname{tr}$ & $\mathrm{ND}$ & $\mathrm{ND}$ \\
$15: 0$ iso & 37.8 & 38.0 & 35.3 & 37.5 & 42.9 & 36.4 & 38.3 \\
$15: 0$ iso 3-OH & 2.8 & 2.1 & 2.0 & 2.7 & 2.8 & 2.2 & 2.4 \\
$15: 0$ anteiso & 2.9 & 2.6 & 6.8 & $\operatorname{tr}$ & 2.3 & 2.2 & 2.7 \\
$16: 0$ & 7.2 & 7.6 & 1.0 & 1.6 & 1.3 & 2.8 & 1.1 \\
$16: 0$ 3-OH & 4.8 & 4.3 & 1.1 & 1.9 & 1.5 & 1.0 & 1.3 \\
$16: 0$ iso 3-OH & $\operatorname{tr}$ & $\operatorname{tr}$ & $\operatorname{tr}$ & $\operatorname{tr}$ & $\operatorname{tr}$ & $\operatorname{tr}$ & $\operatorname{tr}$ \\
Unknown 16.580 & $\operatorname{tr}$ & 1.1 & 1.3 & 1.0 & 1.1 & 1.4 & 1.2 \\
$17: 0$ 2-OH & 1.1 & $\operatorname{tr}$ & 2.5 & $\mathrm{ND}$ & $\operatorname{tr}$ & $\operatorname{tr}$ & $\mathrm{ND}$ \\
$17: 0$ iso & 1.3 & 1.6 & $\operatorname{tr}$ & 1.2 & $\operatorname{tr}$ & 1.9 & 1.2 \\
$17: 0$ iso 3-OH & 16.2 & 15.9 & 14.4 & 15.7 & 17.4 & 13.2 & 16.2 \\
$17: 1$ iso $\omega 9 c$ & 6.6 & 6.5 & 20.7 & 23.1 & 14.8 & 24.4 & 18.7 \\
Summed feature & 12.8 & 13.3 & 10.6 & 9.9 & 10.5 & 9.4 & 10.8 \\
$4 *$ & & & & & & & \\
\hline
\end{tabular}

${ }^{\star}$ Summed feature 4 comprises $16: 1 \omega 7 c$ and/or $15: 0$ iso $2-\mathrm{OH}$, which could not be separated by the MIDI system.

the species description below and those that distinguish them from their closest phylogenetic neighbours are listed in Table 1 . Strains $10-46^{\mathrm{T}}$ and $10-106$ had fatty acid profiles similar to those of their closest phylogenetic neighbours, but they had a larger proportion of 16:0 and a smaller proportion of 17:1 iso $\omega 9 c$ (Table 2).

On the basis of the genotypic and phenotypic data, strains $10-46^{\mathrm{T}}$ and 10-106 are considered to represent a novel species of the genus Chryseobacterium, for which the name Chryseobacterium aquaticum sp. nov. is proposed.

\section{Description of Chryseobacterium aquaticum sp. nov.}

Chryseobacterium aquaticum (a.qua'ti.cum. L. neut. adj. aquaticum living, growing or found in or by water, aquatic).

Cells are Gram-negative, non-motile, non-spore-forming rods, $0.4-0.5 \mu \mathrm{m}$ in diameter and $0.8-2.0 \mu \mathrm{m}$ in length. Catalase- and oxidase-positive. Growth occurs at $5-37{ }^{\circ} \mathrm{C}$ (optimum, $25-30{ }^{\circ} \mathrm{C}$ ) and at $\mathrm{pH}$ 6-8 (optimum, $\mathrm{pH}$ 6-7). Growth occurs in the presence of 1,2 and $3 \% \mathrm{NaCl}$, but not with $5 \%$. No growth is observed on MacConkey agar. Colonies are yellowish, translucent and shiny with entire edges, becoming mucoid after 14 days incubation. Nondiffusible, non-fluorescent, bright-yellow, flexirubin-type pigments are produced on nutrient agar; these pigments turn reddish brown upon addition of $20 \% \mathrm{KOH}$. Indole and $\mathrm{H}_{2} \mathrm{~S}$ are not produced. Nitrate and nitrite are not reduced. Aesculin, casein, gelatin and starch are hydrolysed, but urea is not. Arginine dihydrolase, ornithine decarboxylase, lysine decarboxylase and $\beta$-galactosidase are not produced. Methyl-red test is negative, but VogesProskauer test is positive. In the API 50CH gallery, acid is produced from glucose, fructose, mannose (weakly), rhamnose (weakly), amygdalin (weakly), aesculin, cellobiose (weakly), maltose, melibiose (weakly), sucrose, trehalose, starch, glycogen and gentiobiose, but not from glycerol, erythritol, D- or L-arabinose, ribose, D-xylose, Lxylose, adonitol, methyl $\beta$-D-xylose, galactose, sorbose, dulcitol, inositol, mannitol, sorbitol, methyl $\alpha$-D-mannoside, methyl $\alpha$-D-glucoside, $N$-acetylglucosamine, arbutin, salicin, lactose, inulin, melezitose, raffinose, xylitol, turanose, D-lyxose, D-tagatose, D- or L-fucose, D- or L-arabitol, gluconate, 2-ketogluconate or 5-ketogluconate. The following compounds are utilized as sole carbon sources in GN2 microplates: $\alpha$-cyclodextrin, dextrin, glycogen, Tweens 40 and 80, $\mathrm{N}$-acetyl-D-galactosamine, adonitol, Larabinose, D-arabitol, cellobiose, D-fructose, D-galactose, gentiobiose, $\alpha$-D-glucose, myo-inositol, lactulose, maltose, D-mannose, melibiose, D-psicose, raffinose, L-rhamnose, D-sorbitol, sucrose, trehalose, turanose, xylitol, methyl pyruvate, monomethyl succinate, acetic acid, formic acid, D-galacturonic acid, D-gluconic acid, D-glucosaminic acid, propionic acid, succinic acid, alaninamide, L-alanine, Lalanyl glycine, L-asparagine, L-aspartic acid, L-glutamic acid, glycyl L-aspartic acid, glycyl L-glutamic acid, Lleucine, L-ornithine, L-phenylalanine, L-proline, L-pyroglutamic acid, L-serine, L-threonine, uridine, 2,3-butanediol, DL- $\alpha$-glycerol phosphate, glucose 1-phosphate and glucose 6-phosphate. The following carbon sources are not utilized: $N$-acetyl-D-glucosamine, i-erythritol, L-fucose, methyl $\beta$-Dglucoside, cis-aconitic acid, citric acid, D-galactonic acid lactone, D-glucuronic acid, $\alpha$-, $\beta$ - and $\gamma$-hydroxybutyric acids, $p$-hydroxyphenylacetic acid, itaconic acid, $\alpha$-ketoglutaric acid, DL-lactic acid, D-saccharic acid, sebacic acid, bromosuccinic acid, succinamic acid, glucuronamide, Dalanine, L-histidine, hydroxy-L-proline, D-serine, $\gamma$-aminobutyric acid, urocanic acid, inosine, thymidine, phenylethylamine, putrescine, 2-aminoethanol and glycerol. In the API ZYM gallery, 2-naphthyl phosphate $(\mathrm{pH} 8.5)$, 2-naphthyl butyrate, 2-naphthyl caprylate, L-leucyl 2naphthylamide, L-valyl 2-naphthylamide, L-cystyl 2naphthylamide, $\mathrm{N}$-benzoyl-DL-arginine 2-naphthylamide, 2-naphthyl phosphate ( $\mathrm{pH}$ 5.4) and naphthol-AS-BI-phosphate are hydrolysed, but 2-naphthyl myristate, $N$-glutarylphenylalanine 2-naphthylamide, 6-bromo-2-naphthyl $\alpha$-Dgalactopyranoside, 2 -naphthyl $\beta$-D-galactopyranoside, 
naphthol-AS-BI- $\beta$-D-glucuronide, 2 -naphthyl $\alpha$-D-glucopyranoside, 6-bromo-2-naphthyl $\beta$-D-glucopyranoside, 1-naphthyl $\quad N$-acetyl- $\beta$-D-glucosaminide, $\quad 6$-bromo-2naphthyl $\alpha$-D-mannopyranoside and 2-naphthyl $\alpha$-L-fucopyranoside are not hydrolysed. The only isoprenoid quinone is menaquinone MK-6. The polar lipids comprise phosphatidylethanolamine and several unknown aminolipids. The predominant fatty acids are 15:0 iso $(37.9 \pm 0.1 \%), 17: 0$ iso $3-\mathrm{OH}(16.1 \pm 0.1 \%)$ and summed feature $4(16: 1 \omega 7 c$ and/or $15: 0$ iso $2-\mathrm{OH}, 13.1 \pm 0.2 \%)$. The $\mathrm{G}+\mathrm{C}$ content of the DNA is $38.3-38.5 \mathrm{~mol} \%$ (38.5 $\mathrm{mol} \%$ for the type strain).

The type strain, $10-46^{\mathrm{T}}\left(=\right.$ KCTC $12483^{\mathrm{T}}=$ CECT $\left.7302^{\mathrm{T}}\right)$, was isolated from a water reservoir in Buyeo, Korea. Strain $10-106$, isolated from the same source, is a second strain of the species.

\section{Acknowledgements}

We would like to thank Mi Jeong Kim and Mi Kyung Eom for their expert technical assistance. This work was supported by a grant from the KRIBB Research Initiative Program.

\section{References}

Bates, R. G. \& Bower, V. E. (1956). Alkaline solutions for $\mathrm{pH}$ control. Anal Chem 28, 1322-1324.

Bernardet, J.-F., Hugo, C. \& Bruun, B. (2006). The genera Chryseobacterium and Elizabethkingia. In The Prokaryotes: a Handbook on the Biology of Bacteria, 3rd edn, vol. 7, pp. 638-676. Edited by M. Dworkin, S. Falkow, E. Rosenberg, K. H. Schleifer \& E. Stackebrandt. New York: Springer.

de Beer, H., Hugo, C. J., Jooste, P. J., Vancanneyt, M., Coenye, T. \& Vandamme, P. (2006). Chryseobacterium piscium sp. nov., isolated from fish of the South Atlantic Ocean off South Africa. Int J Syst Evol Microbiol 56, 1317-1322.

Ezaki, T., Hashimoto, Y. \& Yabuuchi, E. (1989). Fluorometric deoxyribonucleic acid-deoxyribonucleic acid hybridization in microdilution wells as an alternative to membrane filter hybridization in which radioisotopes are used to determine genetic relatedness among bacterial strains. Int J Syst Bacteriol 39, 224-229.

Fautz, E. \& Reichenbach, H. (1980). A simple test for flexirubin-type pigments. FEMS Microbiol Lett 8, 87-91.

Felsenstein, J. (1985). Confidence limits on phylogenies: an approach using the bootstrap. Evolution 39, 783-791.

Fitch, W. M. (1971). Toward defining the course of evolution: minimum change for a specific tree topology. Syst Zool 20, 406-416.

Gerhardt, P., Murray, R. G. E., Wood, W. A. \& Krieg, N. R. (1994). Methods for General and Molecular Bacteriology. Washington, DC: American Society for Microbiology.

Gomori, G. (1955). Preparation of buffers for use in enzyme studies. Methods Enzymol 1, 138-146.

Hall, T. A. (1999). BioEdit: a user-friendly biological sequence alignment editor and analysis program for Windows 95/98/NT. Nucleic Acids Symp Ser 41, 95-98.

Jukes, T. H. \& Cantor, C. R. (1969). Evolution of protein molecules. In Mammalian Protein Metabolism, vol. 3, pp. 21-132. Edited by H. N. Munro. New York: Academic Press.
Kämpfer, P. \& Kroppenstedt, R. M. (1996). Numerical analysis of fatty acid patterns of coryneform bacteria and related taxa. Can J Microbiol 42, 989-1005.

Kim, K. K., Kim, M.-K., Lim, J. H., Park, H. Y. \& Lee, S. T. (2005). Transfer of Chryseobacterium meningosepticum and Chryseobacterium miricola to Elizabethkingia gen. nov. as Elizabethkingia meningoseptica comb. nov. and Elizabethkingia miricola comb. nov. Int J Syst Evol Microbiol 55, 1287-1293.

Klatte, S., Rainey, F. A. \& Kroppenstedt, R. M. (1994). Transfer of Rhodococcus aichiensis Tsukamura 1982 and Nocardia amarae Lechevalier and Lechevalier 1974 to the genus Gordona as Gordona aichiensis comb. nov. and Gordona amarae comb. nov. Int J Syst Bacteriol 44, 769-773.

Komagata, K. \& Suzuki, K. (1987). Lipid and cell wall analysis in bacterial systematics. Methods Microbiol 19, 161-207.

Kumar, S., Tamura, K., Jakobsen, I. B. \& Nei, M. (2001). MEGA2: molecular evolutionary genetics analysis software. Bioinformatics $\mathbf{1 7}$, 1244-1245.

Mudarris, M., Austin, B., Segers, P., Vancanneyt, M., Hoste, B. \& Bernardet, J.-F. (1994). Flavobacterium scophthalmum sp. nov., a pathogen of turbot (Scophthalmus maximus L.). Int J Syst Bacteriol 44, 447-453.

Park, M. S., Jung, S. R., Lee, K. H., Lee, M. S., Do, J. O., Kim, S. B. \& Bae, K. S. (2006). Chryseobacterium soldanellicola sp. nov. and Chryseobacterium taeanense sp. nov., isolated from roots of sand-dune plants. Int J Syst Evol Microbiol 56, 433-438.

Rainey, F. A., Ward-Rainey, N., Kroppenstedt, R. M. \& Stackebrandt, E. (1996). The genus Nocardiopsis represents a phylogenetically coherent taxon and a district actinomycete lineage: proposal of Nocardiopsaceae fam. nov. Int J Syst Bacteriol 46, 1088-1092.

Saitou, N. \& Nei, M. (1987). The neighbor-joining method: a new method for reconstructing phylogenetic trees. Mol Biol Evol 4, 406-425.

Sasser, M. (1990). Identification of bacteria by gas chromatography of cellular fatty acids, MIDI Technical Note 101. Newark, DE: MIDI Inc.

Shin, Y. K., Lee, J.-S., Chun, C. O., Kim, H.-J. \& Park, Y.-H. (1996). Isoprenoid quinone profiles of Leclercia adecarboxylata KCTC $1036^{\mathrm{T}}$. J Microbiol Biotechnol 6, 68-69.

Skerman, V. B. K. (1967). A Guide to the Identification of the Genera of Bacteria, 2nd edn. Baltimore: Williams \& Wilkins.

Stackebrandt, E. \& Goebel, B. M. (1994). Taxonomic note: a place for DNA-DNA reassociation and 16S rRNA sequence analysis in the present species definition in bacteriology. Int J Syst Bacteriol 44, 846-849.

Tamaoka, J. \& Komagata, K. (1984). Determination of DNA base composition by reversed-phase high-performance liquid chromatography. FEMS Microbiol Lett 25, 125-128.

Thompson, J. D., Gibson, T. J., Plewniak, F., Jeanmougin, F. \& Higgins, D. G. (1997). The CLUSTAL_X windows interface: flexible strategies for multiple sequence alignment aided by quality analysis tools. Nucleic Acids Res 25, 4876-4882.

Vandamme, P., Bernardet, J.-F., Segers, P., Kersters, K. \& Holmes, B. (1994). New perspectives in the classification of the flavobacteria: description of Chryseobacterium gen. nov., Bergeyella gen. nov., and Empedobacter nom. rev. Int J Syst Bacteriol 44, 827-831.

Wayne, L. G., Brenner, D. J., Colwell, R. R., Grimont, P. A. D., Kandler, O., Krichevsky, M. I., Moore, L. H., Moore, W. E. C., Murray, R. G. E. \& other authors (1987). International Committee on Systematic Bacteriology. Report of the ad hoc committee on reconciliation of approaches to bacterial systematics. Int J Syst Bacteriol 37, 463-464. 